\title{
Study on Chemical Composition and Nutritional Values in the Juice of Citrus Limonia Osbeck
}

\author{
Daw Hla Hla Soe \\ Lecturer, Department of Engineering Chemistry \\ University of Technology, Toungoo \\ Toungoo, Myanmar
}

In this research, the selected Citrus fruit, namely lemon (Citrus limonia Osbeck) was collected from Kay Tu Mady Myothit, Toungoo Township, Pegu Region, Myanmar. According to the phytochemical tests, alkaloids, flavonoids, phenolic compounds, reducing sugar, terpenes, glycosides, tannins and saponins were found to be present in this Citrus fruit while steroids was absent. Nutritional values such as moisture content $(91.86)$, ash content $(0.32 \%)$, protein content $(0.37 \%)$,fiber content $(0.35 \%)$ and fat content $(0.08 \%)$ in juice of Citrus Limon were analyzed by AOAC method. The analysis of some elemental contents presents in juice of Citrus limonia Osbeck were investigated by AAS Method. The vitamin C content $(58 \mathrm{mg} / 100 \mathrm{~mL})$ in juice of Citrus limonia Osbeck was determined by iodometric titration method.

Keywords: Citrus Limon, photochemical investigation, nutritional values, elemental values, vitamin C, AAS

\section{INTRODUCTION}

The lemon (Citrus Limonia) is a species of small evergreen tree native to Asia. The tree's ellipsoidal yellow fruits is used for culinary and non-culinary throughout the world, primarily for its juice, which has both culinary and cleaning uses. The pulp and rind (zest) are also used in cooking and breaking. The juice of the lemon is about $5 \%$ to $6 \%$ citric acid, which gives a sour taste. The distinctive sour taste of lemon juice makes it a key ingredient in drinks and foods such as lemonade and lemon meringue pie.

Lemons are source of vitamin C, providing $64 \%$ of the Daily value in a $100 \mathrm{~g}$ serving (table). Other essential nutrients, however, have insignificant content (table). Lemons contain numerous phytochemicals, including polyphenols and terpenes. As with other citrus fruits, they have significant concentrations of citric acid (about $47 \mathrm{~g} / \mathrm{L}$ ) in juice.

Among the health benefits of lemon highlights its value as anticatarrhal, benefits blood circulation, capillary protector, antispasmodic, diuretic, applied to the skin and mucous membranes is antibacterial and antifungal .
Lemon juice, especially, has several health benefits associated with it. It is well known as a useful treatment for kidney stones, reducing strokes and lowering body temperature. As a refreshing drink, lemonade helps you to stay calm and cool. People use lemons to make lemonade by mixing lemon juice and water. Many people also use lemon as a washing agent, because of its ability to remove stain. Lemon is well known for its medicinal power and is used in many different ways.

\subsection{Botanical Aspect of Lemon}

Family name
Genus
Botanical name
English name
Myanmar name
Part used

Rutaceae

Citrus

Citrus Limon

Lemon

Shauk

Fruits

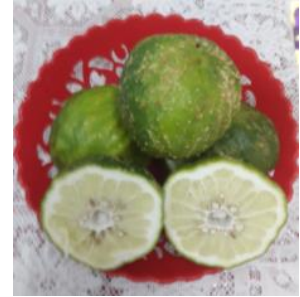

Figure1.Photographs of Citrus limonia Osbeck (Lemon fruit) 


\subsection{Important of lemon juice health care}

Lemon juice is an excellent remedy for scurvy, a disease caused by lack of vitamin C. Vitamin C [ascorbic acid] is found in fruit and vegetables. Hence, scurvy is common among those whose diet is poor in fruits and vegetables. Drink half a glass of lemon juice twice daily. You may sweeten it with honey if you wish. For indigestion, mix half of glass of water and drink daily. This stimulates the activity of the digestive organs and strengthens the system due to the presence of hesperidins, diosmine and other flavonoids, lemon juice and rind improves blood circulation and so are good for edema, hemorrhoids, heart problems stroke and hypertension. It is scientifically proven that lemon produces alkalinity of the system, thus cleansing and reinvigorating the system. For tonsillitis and sore throat, mix half a cup of lemon juice with four dessertspoons of honey. Warm it on fire and use to gaggle every good for washing wounds. Steep a piece of cotton wool in the raw juice and used to clean the wound. Remember that lemon juice is best taken fresh, it is not advisable to store lemon juice for a long time. A lot of people have developed a habit of taking vitamin tablets daily. Lemon is a good source of vitamins. Lemon juice is very good for kidney stones. Citrate [citric acid salts], which are present in lemon, not only prevent formation of kidney stones, but also help dissolve them. Drink half a cup of lemon juice two times daily. You may dilute it with water or sweeten it with honey, depending on your taste. An alternative lemon seeds and then grind into powder. Mix one teaspoons of the powder with two dessertspoons of honey, then lick daily for three weeks. Never mistake the so-called bitter lemon soft drink for real lemon juice, far from it in fact, it is not good for the body as it contains carbonic gas and sugar. For the treatment of arthritis, kidney stones, gout, constipation and hypertension, there is nothing as effective as the famous lemon therapy. Lemon therapy is capable of rejuvenating the body system and clearing the body of all toxins and waste product, giving a feeling of well-being and lightness. Lemon therapy is indispensable in the treatment of cancer. A glass of lemon juice contains less than 25 calories. It is a rich source of nutrients like calcium, potassium, vitamin $\mathrm{C}$ and pectin fibre. It is a rich source of nutrients like calcium, potassium, vitamin $\mathrm{C}$ and pectin fibre. It also has medicinal values and antibacterial properties. It also contains traces of iron and vitamin A. Pure lemon juice contains acid which to tooth enamel. Always dilute with water before drinking it. Lemons that are not washed properly, like the ones you get in restaurants, may include potentially pathogenic microbes.

\subsection{Vitamin C}

Vitamin $\mathrm{C}$ which is also known as ascorbic acid is an essential nutrient for human. It is a water-soluble vitamin that is necessary for normal growth and development. Water soluble vitamins dissolve in water. Left over amount of the vitamin leave the body through the urine. That means a continuous supply of vitamin is needed in daily diet. Vitamin $\mathrm{C}$ is an odorless white solid with the chemical formula of $\mathrm{C}_{6} \mathrm{H}_{8} \mathrm{O}$ 6. It has a molecular mass of 176.14 grams and is so named for its active properties in fighting scurvy. Vitamin $\mathrm{C}$ is a good reducing agent and therefore it is easily oxidized. Vitamin $\mathrm{C}$ can be detected by titrating it against a solution of an oxidizing agent.

Vitamin $\mathrm{C}$ is easily destroyed by heat, alkali and storage. $70 \%$ of vitamin $\mathrm{C}$ is lost in the process of cooking. Vitamin $\mathrm{C}$ is one of group of antioxidants like vitamin $\mathrm{E}$ and $\beta$-carotene to protect the body tissue from damage of oxidation. Vitamin $\mathrm{C}$ is a form of sugar acid that appears white to yellow in a crystal of powder from and is water-soluble. It is found most famously in citrus fruits but also in leafy greens, a staple ingredient used to fortify foods, and is familiar to many as a childhood vitamin supplement, one of the most important for your continued will being [6].

Animals don't get heart attacks because they produce vitamin $\mathrm{C}$ in their bodies, which protects their blood vessel walls. In human, the body does not manufacture vitamin $\mathrm{C}$ on its own, nor does it store it. It is therefore important to include plenty of vitamin $\mathrm{C}$ containing foods in your daily diet. Cardiovascular diesease is an early from of scurvy. Clinical studies document that optimum daily in takes of vitamins and other essential nutrients half and reverse coronary heart disease naturally.

Vitamin $\mathrm{C}$ is found in abundance in fruits and vegetables and in some meats. Rose hips, blackcurrant, peppers, kiwi, guava, broccoli, and nature's most maligned Christmas treat, the Brussels sprout, are all high in vitamin C .Certain meats also contain vitamin $\mathrm{C}$. This is because some animals have high internal levels of $\mathrm{C}$ which build up in certain tissues. Liver is best source of meat for $\mathrm{C}$, but loses up to $100 \%$ of its $\mathrm{C}$ content when cooked. Milk also contains useful amounts of $\mathrm{C}$ for breastfeeding babies.

Cooking and heating destroys many of the active components of vitamin C. Copper cooking vessels also reduce 
the $\mathrm{C}$ content of food. As food is stored, the vitamin $\mathrm{C}$ content gradually decomposes. The fresher the food, the more vitamin $\mathrm{C}$ it will retain. Correct storage in a cool place, such as a refrigerator, also helps maintain vitamin $\mathrm{C}$ content. The levels of vitamin $\mathrm{C}$ in food depend on type of plant, the soil it grew in freshness, how it was stored or prepared.

The National Academy of Sciences recommends the consumption of $60 \mathrm{mg}$ of ascorbic acid day.Vitamin C deficiency, which typically causes abnormalities in bones and teeth.

\section{MATERIALS AND METHODS}

These fresh Fruit were lemon (Citrus limonia Osbeck) was collected from Kay Tu Mady Myothit, Toungoo Township, Pegu Region, Myanmar. These fresh Fruits were peel off and made into juice by squeezing. Strain the juice through a coffee filter or cheese cloth to remove pulp and seeds. Then, the fresh juice taken to carried out the experiment.

\subsection{Preliminary Phytochemical Investigation in} Juice of Citrus limon

In order to find out the types of organic constituents present in the sample, preliminary phytochemical investigation was carried out according to the appropriate reported methods.

\subsubsection{Test for Alkaloids}

About $5 \mathrm{ml}$ of $1 \%$ hydrochloric was to the crude sample and warmed in water-bath for 15 minutes and then filtered. The filtrate was divided into three portions and they were tested with $1 \mathrm{~mL}$ of Mayer's reagent respectively. Observation was carried out to see whether color p.pt was formed or not.

\subsubsection{Test for Flavonoids}

$3 \mathrm{~g}$ of sample was extracted with $20 \mathrm{~mL}$ of $96 \%$ ethanol. The solution was divided through a cotton-fitter. 1-2 drops of concentrated hydrochloric acid and then small pieces of magnesium turnings were added into the filtrate. Observation was carried out to see whether the color of the solution turned or not within ten minutes.

\subsubsection{Test for Phenolic Compounds}

$3 \mathrm{~g}$ of the sample was mixed with $10 \mathrm{~mL}$ of distilled water and heated in a water bath for 30 minutes. The solution was filtered through a cotton-filter. 3 drops of a mixture of $1 \mathrm{~mL} 1 \%$ $\mathrm{FeCl}_{3}$ and $1 \% \mathrm{~K}_{3}\left[\mathrm{Fe}(\mathrm{CN})_{6}\right]$ were added into the filtrate. Observation was carried out to see whether a green or blue color was developed or not.

\subsubsection{Test for Steroids}

$5 \mathrm{~g}$ of crude sample were extracted with $30 \mathrm{~mL}$ of $65 \%$ ethanol.

\subsubsection{Libermann Burchard Reactions}

The extracted solution was treated with $0.3 \mathrm{~mL}$ of acetic anhydride and gently warmed, and then a few drops of concentrated sulphuric acid were added. Observation was carried out to see whether the color of the solution turned or not within one hour.

\subsubsection{Salkowski Reaction}

$1 \mathrm{ml}$ of sulphuric acid was mixed with small amount of crude sample dissolved in $10 \mathrm{~mL}$ of chloroform solution.

Observation was carried out to see whether pink color of sulphuric acid layer changed to brown or not.

\subsubsection{Test for Glycosides}

The Crude sample was dissolved in $5 \mathrm{~mL}$ of distilled water and $10 \%$ sodium hydroxide solution was added. Observation of color changes was carried out. The crude $2 \mathrm{~g}$ of sample was extracted with $10 \mathrm{~mL}$ of $95 \%$ ethanol. The crude extract was added with $10 \%$ lead acetate solution. Observation was carried out to see whether white p.pt formed or not.

\subsubsection{Test for Tannins}

$2 \mathrm{~g}$ of crude sample were heated with $10 \mathrm{~mL}$ of distilled water for 30 minutes on a water bath and the solution was filtered. $3 \mathrm{~mL}$ of $2 \% \mathrm{NaCl}$ solution was added to the filtrate and then 1 $\mathrm{mL}$ of $\mathrm{FeCl}_{3}$ solution was added in it.

Observation was carried out to see whether p.pt was formed or not.

\subsubsection{Test for Reduction Sugar}

The sample was mixed with $20 \mathrm{ml}$ of distilled water and heated in a water bath for 30 minutes. The solution was added into the filters.

Observation was carried out to see whether red p.pt was formed or not.

\subsubsection{Test for Terpenes}

$2 \mathrm{~g}$ of sample was mixed with $20 \mathrm{~mL}$ of pet-ether. Two Drops of extracted solution was placed in test tube. Then three drops of acetic anhydride, four drops of chloroform $\left(\mathrm{CHCL}_{3}\right)$ and one drop of concentrated sulphuric acid were added in this test tube and shaken for 30minutes.

Observations was carried out to see whether the color of the solution turned or not. 


\subsubsection{Test for Saponins}

To the sample (2 $\mathrm{g}), 5 \mathrm{~mL}$ of distilled water was and added and shaken vigorously. Observation was made to see if frothing in solution indicated the presence of saponin.

\subsection{Nutritional Analysis}

Moisture content in the sample was determined by electric oven method (Egan, Kirk and Sawyer, 1981). Ash content of the sample was determined by the method given in "The Chemical Analysis of Foods", (Joslyn, 1970, Official and Tentative Methods of American Chemist's Society, 1955). Crude fiber content in the sample was determined by this method given in "A manual of laboratory techniques" (Raghuramulu, 1983). Protein content in the sample was determined by macro-kjeldahl Method (William, 1984). Fat content was determined by the soxhlet extraction method (pearson, 1976) using petroleum ether.

\subsection{Elemental Analysis by Atomic} AbsorptionSpectrophotometry (AAS)

The analysis of mineral elements was carried out by DAR (Department of agricultural research Ye zin, Myanmar)

\subsubsection{Sample treatment}

The juice samples was weighed and then pre-ash was carried out on a hot plate until all the combustible materials were burnt. Pre-ash sample were placed inside the furnace (electric muffle furnace) and heated gradually raising temperature until $450^{\circ} \mathrm{C}$. The process of heating, cooling and weighting were repeated until constant weight of ash samples were obtained.

For determination by AA, about $1 \mathrm{~g}$ of shed sample were accurately weighed and dissolved $2 \mathrm{~cm}^{3}$ of concentrated sulphuric acid. The resulting solutions of ash were evaporated to dryness and dissolved in $6 \mathrm{~cm}^{3} 25 \%$ HCL solution(v/v) followed by centrifuged solution was decanted and the color solution were made up to $1000 \mathrm{~cm}^{3}$ with deionized water. The resulting solutions $\left(10 \mathrm{~cm}^{3}\right)$ were pipetted accurately. The sample solution prepared was ready analysis of mineral elements by AAS.

\subsubsection{Determination of trace elements with Atomic} Absorption Spectrophotometry

Atomic Absorption Spectrophotometer (Perkin-Elma A Analyst 880)) was used for analyzing the sample solution prepared. The method involves the absorption of radiation by the atomic vapor produced from the sample solutions at a wavelength that is characteristic of element being determined
(Lajunen, 1991). The sample solution is aspirated into the flame that is irradiated by light from hollow cathode lamp that emits light of a wavelength characteristic of that element. The degree of the absorption is related to the concentration of the atom in the found state, therefore to the concentration of the atom in the ground state, therefore to the concentration of the element and it measured photometrically. This method is particularly suitable for analysis of microcomponents or trace elements.

\subsection{Determination of Vitamin C Content in} Fruit Juice by an Iodometric Titration

\subsubsection{Iodometric titration}

Vitamin C can be determined in fruit juice by use of an oxidation-reduction reaction. The redox reaction is preferable to an acid -base titration because a number of other species in juice can act as acids, but relatively few interfere with the oxidation of ascorbic acid by iodine. The solubility of iodine is increased by complexation with iodide to form triiodide. The end point is indicated by the reaction of iodine with starch, which produces a blue-black product. As long as vitamin $\mathrm{C}$ is present, the triiodide is quickly converted to iodide ion, and no blue-black iodinestarch product is observed. However, when all the vitamin Chas been oxidized, the excess triiodide (in equilibrium with iodine) reacts with starch to from the expected blue-black color.

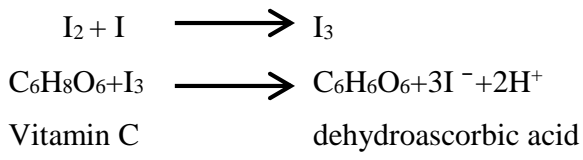

Sample: Lemon Juice

Apparatus: Burette, pipette, conical flask, measuring cylinder, reagent bottle, volumetric flask.

\subsubsection{Preparation of solution}

1\% Starch Indicator Solution (add $0.5 \mathrm{~g}$ soluble starch to $50 \mathrm{ml}$ near-boiling distilled water. Mix well and allow to cool before use). Iodine Solution (dissolve $2.5 \mathrm{~g}$ of potassium iodide and $0.134 \mathrm{~g}$ of potassium iodate in $100 \mathrm{~mL}$ of distilled water. Then $3 \mathrm{M}$ sulfuric acid $15 \mathrm{~mL}$ was added to above solution. Pour this solution into a graduated cylinder and dilute it to a final volume of $250 \mathrm{~mL}$ with distilled water). Vitamin C Standard Solution (standard ascorbic acid $(0.25 \mathrm{~g})$ was dissolved in distilled water and the volume made up to $250 \mathrm{~mL}$ in a volumetric flask). 
2.4.1.2 Standardization of iodine solution with vitamin $\mathbf{C}$ standard solution

Add $25.0 \mathrm{ml}$ of vitamin $\mathrm{C}$ standard to a $150 \mathrm{~mL}$ conical flask. Add 10 drops of $1 \%$ starch solution. Rinse the burette with a small volume of the iodine solution and fill it. Record the intimal volume. Titrate the solution until the endpoint is reached. Record the final volume. Repeat the titration at least three times. The result should agree within $0.1 \mathrm{ml}$.Titration of fruit Juice Sample Add $25.0 \mathrm{~mL}$ of fruit juice sample into $150 \mathrm{~mL}$ conical flask. Repeat the titration until at least three measurement that agree to within $0.1 \mathrm{ml}$.

Calculate the molarity of the iodine solution using standard ascorbic acid. Calculate the amount of vitamin $\mathrm{C}$ in fruit juice including the volume of titrant used, the mole of vitamin $\mathrm{C}$ present, the molarity of vitamin $\mathrm{C}$ and concentration of vitamin $\mathrm{C}$ in $\mathrm{mg} / 100 \mathrm{ml}$.

\section{RESULT AND DISCUSSIONS}

\subsection{Preliminary Phytochemical Investigation on} fruit juice

The investigation was carried out to analyze the different types of compound present in lemon juice. The qualitative phytochemical analysis in juice of Citrus Limon showed the presence of alkaloids, flavonoids. Phenolic compounds, reducing sugar, terpenes, glycosides, tannins and saponins and except steroids. The results are shown in table (1).

Table (1) Result of Phytochemical in Juice of Citrus Limonia Osbeck

\begin{tabular}{|c|c|c|c|c|c|}
\hline No & $\begin{array}{c}\text { Types of } \\
\text { compounds }\end{array}$ & Extract & Reagent used & Observation & Result \\
\hline 1 & Alkaloids & $1 \% \mathrm{HCL}$ & $\begin{array}{ll}\text { (i) } & \text { Mayer reagents } \\
\text { (ii) } & \text { Wagner's reagents }\end{array}$ & $\begin{array}{l}\text { White p.pt } \\
\text { Brown p.pt }\end{array}$ & $\begin{array}{l}+ \\
+\end{array}$ \\
\hline 2 & Flavonoids & $95 \% \mathrm{Et} \mathrm{OH}$ & Conc: $\mathrm{HCl}$ and $\mathrm{Mg}$ Turnings & Prink color & + \\
\hline 3 & $\begin{array}{c}\text { Phenolic } \\
\text { Compounds }\end{array}$ & $\begin{array}{l}\text { Distilled } \\
\text { water }\end{array}$ & 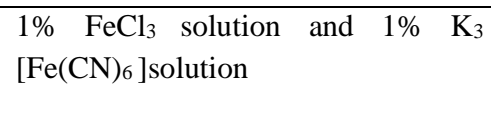 & Green & + \\
\hline 4 & Steroids & $95 \% \mathrm{EtOH}$ & Acetic Anhydride and con: $\mathrm{H}_{2} \mathrm{SO}_{4}$ & $\begin{array}{l}\text { No color } \\
\text { change }\end{array}$ & - \\
\hline 5 & Glycosides & $\begin{array}{c}\text { Distilled } \\
\text { water }\end{array}$ & $10 \% \mathrm{NaOH}$ solution & Yellow color & + \\
\hline 6 & Tannins & $\begin{array}{l}\text { Distilled } \\
\text { water }\end{array}$ & $\begin{array}{lllll}2 \% \mathrm{NaCl} & \text { solution and } & 1 \% & \mathrm{FeCl}_{3} \\
\text { solution } & & & & \\
\end{array}$ & Green p.pt & + \\
\hline 7 & Reducing sugar & $\begin{array}{l}\text { Distilled } \\
\text { water }\end{array}$ & Benedict's solution & Red p.pt & + \\
\hline 8 & Terpenes & Pet- Ether & $\begin{array}{l}\text { Acetic anhydride, } \\
\text { Chloroform and con: } \mathrm{H}_{2} \mathrm{SO}_{4}\end{array}$ & $\begin{array}{l}\text { Yellowish } \\
\text { Green color }\end{array}$ & + \\
\hline 9 & Saponins & $\begin{array}{c}\text { Distilled } \\
\text { water }\end{array}$ & Shaken Vigorously & $\begin{array}{l}\text { Frothing in } \\
\text { Solution }\end{array}$ & + \\
\hline
\end{tabular}

$(+)=$ presence

$(-)=$ absence

$(\mathrm{p} . \mathrm{pt})=$ precipitate 


\subsection{Determination of Nutritional Values in Juice} of Citrus Lemon

Lemon Juice (Citrus Limon) is well known for the rich nutrient contents. Change in nutrient composition from harvest to consumption depend to a certain degree on the particular nutrient, the commodity, and the postharvest handing storage. In addition, initial nutrient content is affected by the particular cultivar, soil type, production system and weather conditions (temperature, humidity, daylight hours. ect....) during growth. The nutritional values such as fat, protein carbohydrate and fibre content were determined. As a result, it was found that carbohydrate, protein and fibre are present as major nutrients in lemon juice. The quantitative analyzes, namely determination of moisture, nitrogen and ash contents were according to methods described in the experimental section (2.2). The results are in table (2).

Table (2) Results of Nutrient Values for the Juice of Citrus Limonia Osbeck

\begin{tabular}{|c|l|l|}
\hline No & Principle Contents & Nutritional value (\%) \\
\hline $\mathbf{1}$ & Moisture content & 91.86 \\
\hline $\mathbf{2}$ & Ash content & 0.32 \\
\hline $\mathbf{3}$ & Protein content & 0.37 \\
\hline $\mathbf{4}$ & Fibre content & 0.35 \\
\hline $\mathbf{5}$ & Fat content & 0.08 \\
\hline
\end{tabular}

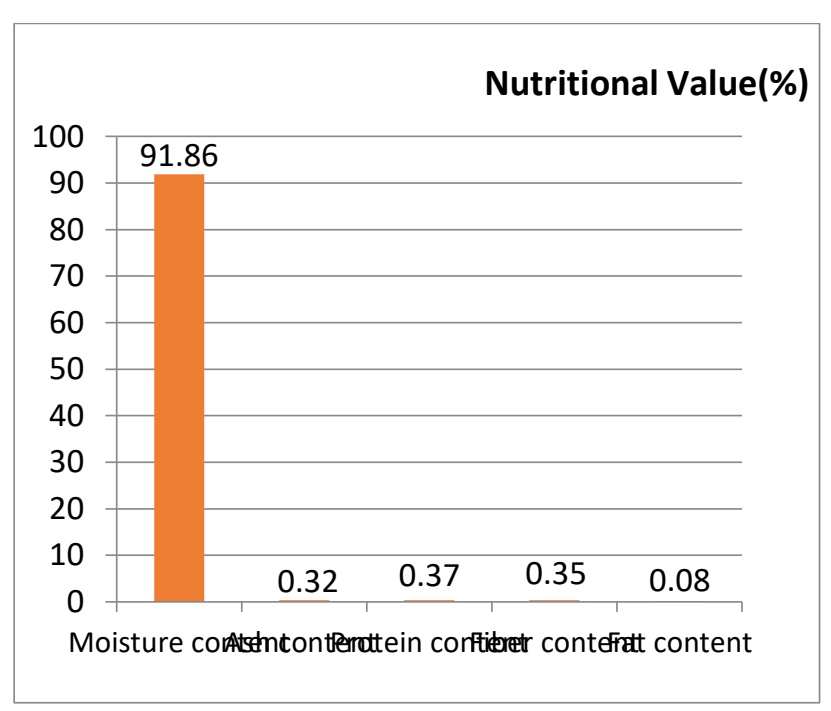

Figure (2) Histogram for Nutritional Values of Juice of Citrus Limon

\subsection{Elemental contents in Juice of Citrus lemon by} Atomic Absorption Spectrophotometry

The amount of minerals in the plant should be determined because they play an important role in the life cycle of plant as well as for humans. In the determination of minerals from lemon juice, the ash of plant material was prepared by heating the substance in the furnance. The elemental contents of lemon juice were performed by AAS as described in section 2.3. As a result, $\mathrm{Na}, \mathrm{K}, \mathrm{Ca}, \mathrm{Mg}, \mathrm{Fe}$ and $\mathrm{As}, \mathrm{Ag}, \mathrm{Cu}, \mathrm{Pb}, \mathrm{Zn}$ were detected in lemon juice. The elemental contents are shown in table (3).In the present study, $\mathrm{As}, \mathrm{Ag}, \mathrm{Cu}, \mathrm{Pb}$ and $\mathrm{Zn}$ contents of lemons juice were not detected. Calcium content was found to be the highest followed by sodium, potassium, magnesium and iron. The results are in table (3) and Figure (3).

Table (3) Element Analysis in Juice of Citrus limonia Osbeck by Atomic Absorption Spectrophotometry (AAS)

\begin{tabular}{|l|c|c|}
\hline No & Elements & Elemental Contents(ppm) \\
\hline 1 & $\mathrm{Na}$ & 13.17 \\
\hline 2 & $\mathrm{~K}$ & 10.54 \\
\hline 3 & $\mathrm{Ca}$ & 15.18 \\
\hline 4 & $\mathrm{Mg}$ & 7.85 \\
\hline 5 & $\mathrm{Fe}$ & 2.18 \\
\hline 6 & $\mathrm{Cu}$ & $\mathrm{ND}$ \\
\hline 7 & $\mathrm{Zn}$ & $\mathrm{ND}$ \\
\hline 8 & $\mathrm{~Pb}$ & $\mathrm{ND}$ \\
\hline 9 & $\mathrm{Ag}$ & $\mathrm{ND}$ \\
\hline 10 & $\mathrm{As}$ & $\mathrm{ND}$ \\
\hline
\end{tabular}

$\mathrm{ND}=$ Not Detected 


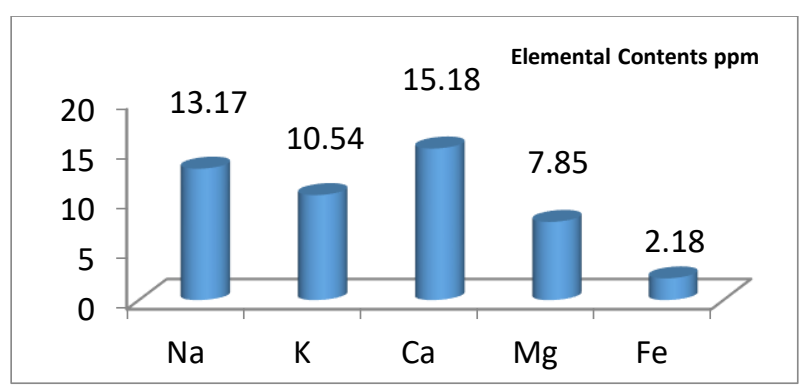

Figure (3) The Elemental Contests Present in juice of Citrus limon by AAs Method

\subsection{Determination of Vitamin C Content in}

\section{Lemon Juice}

In the Present work, the vitamin $\mathrm{C}$ content in lemon juice was measured by iodometric titration method, Vitamin $\mathrm{C}$ content in lemon juice is shown in Table (4)

Table (4) Vitamin C Content in juice of citrus limonia

\begin{tabular}{|c|c|c|}
\hline No & Sample & $\begin{array}{c}\text { Vitamin C content } \\
(\mathrm{mg} / 100 \mathrm{~mL})\end{array}$ \\
\hline 1 & Lemon Juice & 58.08 \\
\hline \multicolumn{2}{|c|}{ From experimental data, it was seen that the vitamin C }
\end{tabular}

content in $100 \mathrm{~mL}$ lemon juice was $58.08 \mathrm{mg}$.

\section{CONCULATION}

From the overall assessments of the present work, the following inference can be deduced.

The qualitative phytochemical in juice of Citrus limon showed the presence of alkaloids, flavonoids, phenolic of compounds, reduction sugar, terpenes, glycosides, tannins and saponins and except steroids. The qualitative test was justified by their color changes with their various reagents.

From nutritional values determination, moisture content (91.86), ash content (0.32), protein content, (0.37), fibre content $(0.35)$ and fat content $(0.08)$ were observed to be present in lemon juice sample.

From the elemental analysis of juice of Citrus limonia Osbeck Na (13.17 ppm), K (10.54 ppm), Ca (15.18ppm), Mg (7.85 ppm) and Fe (2.18 ppm) were found to be presented. The relatively high contents of $\mathrm{Ca}, \mathrm{Na}$ and $\mathrm{K}$ were detected and the contents of $\mathrm{Cu}, \mathrm{Zn}, \mathrm{Pb}, \mathrm{Ag}$ and $\mathrm{As}$ were not detected in juice of Citrus limonia Osbeck.

The vitamin $\mathrm{C}$ content of lemon juice can be seen that $58.08 \mathrm{mg} / 100 \mathrm{~mL}$ by iodometric titration method.

\section{ACKNOWLEDGEMENTS}

Firstly, I would like to give my acknowledgement to Dr. Maung Maung Latt, Rector of Technological University (Toungoo) for his encourage for this paper together with me and advised me to. I offer my sincere thanks to all who help me with required assistance.

\section{REFERENCES}

[1] Egan, H, Kirk, R.S., and Sawyer, R., (1981), “pearson’s Chemical Analysis of Food's, Churchill Livingstone Inc.,London, p 123.

[2] Hutchison. J (1964). The general of flowering plants. Volume I, II. London; Oxford University Press, Amon House.

[3] Jeffery B. Harborne, Herbert Baxter,(1993)., "Phytochemical Dictionary". A hand book of bioactive compounds from plants. London. Washington, DC.

[4] J.B Harbone,(1984); Phytochemical Methods; $2^{\text {nd }}$ Edition. A Guide to modern Techniques of Plants Analysis, Chpman and Hall Ltd., USA

[5] Kapoor,L.D.(2001),Han book ofAyurvedic Medical Plants. National Botanical Research Institute, Lucknown Council of Scientific.

[6] Julia F. Morton (1987). "Lemon in fruits of Warm Climate". Purdue University. pp. 160-168.

[7] Lajunen, L.H,J., (1991), "Spectrochemical Analysis by Atomic Absorption and Emission", The Royal Society of Chemistry, British Library, Cambridge

[8] "Lemon (Citrus) Superlative 6 Health Benefits" Effect Home Remedy. May 29, 2019. Retired June 2019.

[9] Nakada SY, Holmes RP, Assimos DG (2008) of Citrus Acid in lemon, and commercially.

[10] Rauf A, Uddin G, Alij (2014). "Pyrochemical analysis and radical scavenging profile of juices of Citrus limonium”. Org. Med. Che. lett.

[11] Wilsom, J.X., (2005), "Regulation of vitamin C Transport", Annu.Rev.Nutr.25, 1-25

[12] Yadav, N, and Agarwals, M., (2011), "Phytochemical Analysis of some Mechanical Plants", Journal of Phytology, 3(12), 10-14. 